Bhattacharya et al. International Journal Of Recycling of Organic

Waste in Agriculture 2013, 2:19

http://www.ijrowa.com/content/2/1/19
0 International Journal of

Recycling of Organic Waste in Agriculture

a SpringerOpen Journal

\title{
Combination technology of ceramic microfiltration and biosorbent for treatment and reuse of tannery effluent from different streams: response of defence system in Euphorbia sp.
}

Priyankari Bhattacharya', Sourja Ghosh ${ }^{1 *}$ and Aniruddha Mukhopadhyay ${ }^{2}$

\begin{abstract}
Background: The present study was undertaken to evaluate the efficiency of combined technology involving ceramic microfiltration and biosorbent for the treatment of tannery effluent from different streams, viz. composite effluent, effluent from primary clarifier and secondary clarifier. The membranes were prepared from a cost-effective composition of alumina and clay.

Results: The effluents had high organic loading of 12,895, 3,890 and $410 \mathrm{mg} / \mathrm{L}$, respectively, in terms of chemical oxygen demand (COD). Apart from these, the effluents consisted of toxic heavy metals, turbidity, biochemical oxygen demand (BOD), etc. It was observed that COD reduction was about $96.5 \%$ for effluent $1,96.6 \%$ for effluent 2 and $96.9 \%$ for effluent 3. Considerable reduction in suspended solids, total nitrogen, and total organic carbon was obtained. Turbidity for all three types of effluent was below 1 NTU. The average flux value for effluents 1, 2 and 3 was about 13,19 and $24 \mathrm{~L} / \mathrm{m}^{2} / \mathrm{h}(\mathrm{LMH})$, respectively. Response of the antioxidative defences of Euphorbia hirta was observed which resulted in considerable decrease in the activity of peroxidase, superoxide dismutase and catalase.

Conclusions: The treatment resulted in the reduction of toxicity thereby restoring normal activity when compared to control values. Changes in various biochemical parameters like protein, amino acid, carbohydrate, DNA, RNA and chlorophyll content were observed.
\end{abstract}

Keywords: Tannery effluent; Biosorbent; Ceramic membrane; Microfiltration; Reuse; Euphorbia sp

\section{Introduction}

The most polluting and oldest industry of the world is tanning industry. The demand for leather products is increasing with increasing population, thereby creating huge pollution load on the environment. The different processes associated with leather processing and finishing require huge amount of toxic chemicals, lime, chloride and the hides itself that contain huge amount of organic matter, protein and fats which contribute to the effluent when discharged into the environment (Altaf et al. 2008). Therefore, the most important challenge that scientists all over the world are facing is the treatment of tannery wastewater

\footnotetext{
* Correspondence: sourja@cgcri.res.in

${ }^{1}$ Ceramic Membrane Division, CSIR-Central Glass and Ceramic Research

Institute, 196 Raja S.C. Mullick Road, Kolkata 700032, India

Full list of author information is available at the end of the article
}

to make it reusable. Various methods have been explored for the treatment of tannery wastewater. The most conventional treatment option is biological treatment which has been successfully applied for many years (Vasudevan et al. 2012; Sivaprakasam et al. 2008). But due to the generation of large volume of sludge, this option has its own drawbacks. Apart from this, other processes like Fenton's and electro-oxidation (Rameshraja and Suresh 2011), photolytic and electrolytic oxidation (Anglada et al. 2009), ozonation (Dogruel et al. 2004), coagulation (Espinoza-Quinones et al. 2009), $\mathrm{UV} / \mathrm{H}_{2} \mathrm{O}_{2}$ (Rodrigues et al. 2008), etc. have been applied. Adsorbents prepared from natural materials have been used for the removal of chromium from tannery wastewater. The applicability of novel biosorbents had been studied for the removal of chromium from tannery wastewater (Chena et al. 2011; Bhattacharya et al. 2013). 
Membrane-based treatment of wastewater is being explored recently due to its efficiency and less generation of sludge. Membrane bioreactors are being widely used for the treatment of tannery and other wastewater (Cassano et al. 2001; Stephenson et al. 2000; Suthanthararajan et al. 2004.) Scholz et al. (2005) has studied the use of a membrane bioreactor for the removal of organic pollutants and suspended solids from tannery effluent and followed it up with the use of reverse osmosis. Goltara et al. (2009) studied membrane sequencing batch reactor for the treatment of beam house effluent. Use of a hybrid membrane bioreactor consisting of electro-coagulation, biological treatment and microfiltration was investigated for the removal of colour and chemical oxygen demand (COD) from tannery wastewater (Keerthi et al. 2013).

Ceramic membranes have been developed indigenously from a cost-effective composition of clay and alumina by the CSIR-Central Glass and Ceramic Research Institute. These membranes have been successfully used for the treatment of various types of wastewater (Bandyopadhyay et al. 2006; Bhattacharya et al. 2010, 2011). Therefore, in the present study, an attempt was undertaken to treat tannery effluent collected from different streams using the combined technology of biosorbent and ceramic microfiltration. To observe the reuse efficiency of the treated water, effect on various biochemical parameters and antioxidative enzymes was observed on the herb Euphorbia hirta L. The reason for choosing this plant was that this plant was widely grown in and around areas near the tannery industry. These herbs are widely grown and very common in tropical countries (Tabugo et al. 2013). It is widely distributed throughout India near roadsides (Prajapati et al. 2003). In this case, the herbs were found to grow along the roadside of the effluent collection plant. E. hirta is a weed that grows profusely in waste places. It is an invasive plant which spreads very quickly and is a species of much brightened environment that grows so well on dry grounds as well as in the wetter zones. The herb prefers sandy grounds or gravels and grows in sunny to lightly shaded, not too moist, grassy sites, between stones and waste areas (Holm et al. 1991). But interestingly, the plants grown adjacent to the tank from where composite wastewater was collected were highly affected in terms of leaf growth, appearances, browning of leaves, etc. This might have occurred due to wastewater that seeped through cracks on the tank wall. But the plants that grew near a secondary clarifier tank were quite healthy. This drew attention, and the authors observed the effect of treated and untreated wastewater on this plant. The plant belongs to the family Euphorbiaceae and is characterized by the presence of white milky latex. This plant and other species of this genus have been used to prepare traditional medicines as it has antibacterial, antifungal, antimalarial activity, etc. Effect on E. hirta L. exposed to coal smoke pollutants for a long time was studied. Reduced plant growth and variations in stem anatomy, as well as chlorophyll content, resulting from the pollutants were observed (Gupta 1987). In the current study, the effects on $E$. hirta with respect to oxidative stress enzymes like superoxide dismutase (SOD), catalase (CAT) and guaiacol peroxidase (POD) in response to treated and untreated tannery effluent from different streams were observed. Moreover, the effect on chlorophyll content, amino acid, carbohydrate, DNA and RNA content was also studied. These studies were undertaken to investigate the toxicity response of living plants towards treated effluent in comparison with untreated effluent to understand the environmental impact of the proposed treatment scheme.

\section{Methods}

\section{Collection of effluent}

The study was conducted on three different loadings of wastewater, viz. composite wastewater (effluent 1), effluent from primary clarifier (effluent 2) and secondary clarifier (effluent 3). The effluents were collected from a common effluent treatment plant of tannery wastewater located at Kolkata, India. A schematic representation of the common effluent treatment plant is depicted in Figure 1. Immediately after collection, the wastewater was subjected to various characterizations according to the standard methods for water and wastewater (Greenberg et al. 2005), as shown Table 1.

\section{Batch biosorption study}

Biosorption study was conducted at varying $\mathrm{pH}$ (1 to 9) and biosorbent dose $(0.25$ to $5 \mathrm{~g} / \mathrm{L})$ for three different effluents to optimize the process parameters. A novel biosorbent prepared from fruit peels of Trewia nudiflora was used. The biosorbent was prepared by subjecting the fruit peels to phosphoric acid treatment for surface activation (Bhattacharya et al. 2013).

\section{Crossflow microfiltration study}

Crossflow microfiltration study was conducted using an indigenously developed ceramic multichannel element with a diameter of $35 \mathrm{~mm}$, length of $200 \mathrm{~mm}$ and channel diameter of $4 \mathrm{~mm}$. Average pore size of the membrane was about $1 \mu \mathrm{m}$. The membrane was placed inside a stainless steel module horizontally aligned in the setup. The ceramic membrane was stable at a wide range of $\mathrm{pH}$ (2 to 12). The operating pressure limit of the current study was 0.4 to $2.2 \mathrm{~kg} / \mathrm{cm}^{2}$ although the membrane could withstand an external pressure up to $6 \mathrm{~kg} / \mathrm{cm}^{2}$. A centrifugal pump with $1 \mathrm{hp}$ capacity was provided for recirculation of the feed water, and permeate samples were collected from the bottom port. The capacity of the feed tank was $10 \mathrm{~L}$. A schematic representation of 


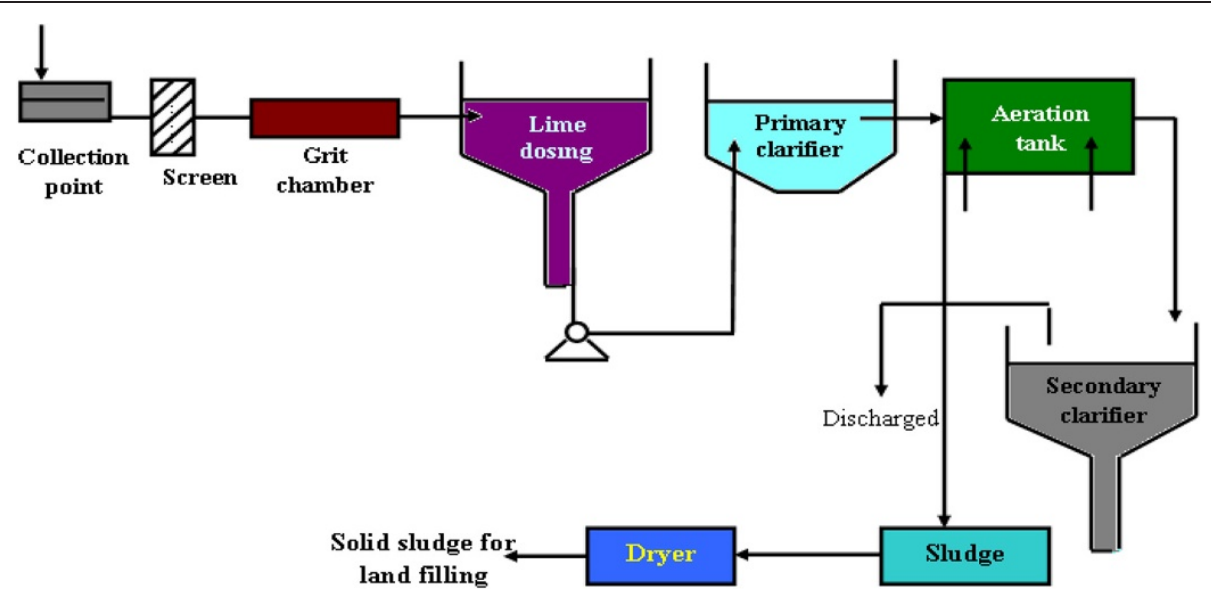

Figure 1 Schematic representation of conventional treatment in common effluent treatment plant.

the experimental process was shown in Figure 2. The study was conducted using three different types of feed, i.e. effluents 1, 2 and 3. Each study was conducted using three different feeds for each type of effluent. The effluent along with the optimized dose of biosorbent was taken to the feed tank and recirculated for about $30 \mathrm{~min}$ to ensure proper mixing. The $\mathrm{pH}$ of the effluent was adjusted to optimum value by adding dilute acid or alkali solution. The setup was allowed to run at $1 \mathrm{~kg} / \mathrm{cm}^{2}$ transmembrane pressure for about $180 \mathrm{~min}$ to observe the effect of time on permeate flux. Effect transmembrane pressure was observed by varying the pressure from 0.4 to $2.2 \mathrm{~kg} / \mathrm{cm}^{2}$.
Permeate samples were collected at definite time intervals to measure COD (Spectralab, Mumbai, India), total kjeldahl nitrogen (TKN) (Pelican Instruments, Chennai, India), turbidity (Hach, Loveland, CO, USA), pH (Hach), conductivity (Hach), total dissolved solids (TDS) (Hach), total suspended solids (TSS) (Tarsons, Kolkata, India), biochemical oxygen demand (BOD) (Hach), etc. After each run, the experimental setup was cleaned with distilled water, and after completion of all the experiments, it was cleaned thoroughly with $0.1(\mathrm{~N})$ of nitric acid solution, then $0.1(\mathrm{~N})$ of sodium hydroxide solution followed by washing with deionized water. Washing was continued until clean

Table 1 Characteristics of tannery wastewater

\begin{tabular}{|c|c|c|c|c|c|c|c|}
\hline \multirow[t]{2}{*}{ Parameters } & \multicolumn{2}{|c|}{ Effluent 1} & \multicolumn{2}{|c|}{ Effluent 2} & \multicolumn{2}{|c|}{ Effluent 3} & \multirow{2}{*}{$\begin{array}{c}\text { Discharge } \\
\text { norms }^{\mathrm{a}}\end{array}$} \\
\hline & Untreated & $\begin{array}{c}\text { Treated } \\
(A D+M F)\end{array}$ & Untreated & $\begin{array}{c}\text { Treated } \\
(A D+M F)\end{array}$ & Untreated & $\begin{array}{c}\text { Treated } \\
(A D+M F)\end{array}$ & \\
\hline $\mathrm{pH}$ & 8.21 & 7.25 & 7.34 & 7.21 & 6.29 & 6.24 & 6.0 to 9.0 \\
\hline COD (mg/L) & 12,895 & 442 & 3,890 & 261 & 410 & 35 & - \\
\hline BOD (mg/L) & 1,089 & 52 & 439 & 21.1 & 47 & 6.2 & 30 \\
\hline TSS (mg/L) & 1,088 & 2.4 & 282 & 1.11 & 34 & 4.8 & 100 \\
\hline TDS (mg/L) & 8,852 & 7,421 & 6,605 & 5,881 & 3,895 & 2,899 & - \\
\hline TKN (mg/L) & 29.5 & 4.1 & 21.2 & 2.9 & 8.6 & 0.5 & - \\
\hline TOC (mg/L) & 580 & 46.8 & 374 & 26.8 & 10.8 & 0.75 & \\
\hline Conductivity (mS/cm) & 14.89 & 11.25 & 13.41 & 10.6 & 7.87 & 2.99 & - \\
\hline Turbidity (NTU) & 1,193 & 0.664 & 256 & 0.625 & 12.2 & 0.341 & - \\
\hline Chromium (mg/L) & 60 & 0.02 & 20 & ND & 0.3 & ND & 0.1 \\
\hline Magnesium (mg/L) & 920 & 27.26 & 730 & 15.44 & 22.1 & 1.91 & - \\
\hline Potassium (mg/L) & 550 & 11.2 & 490 & 9.5 & 61.4 & 0.71 & - \\
\hline Phosphorus (mg/L) & 710 & 20.6 & 580 & 17.4 & 8.0 & 1.55 & - \\
\hline Nickel (mg/L) & 80 & 1.12 & 70 & 7.6 & 0.1 & 0.04 & - \\
\hline Lead (mg/L) & 60 & 0.06 & 40 & 0.04 & 0.4 & ND & - \\
\hline Sulphide (mg/L) & 382 & 11.4 & 382 & 8.4 & 70.1 & 1.3 & 2.0 \\
\hline
\end{tabular}

Data represent average of triplicates. ND, not detected. ${ }^{a}$ The Environment (Protection) Rules (1986). 


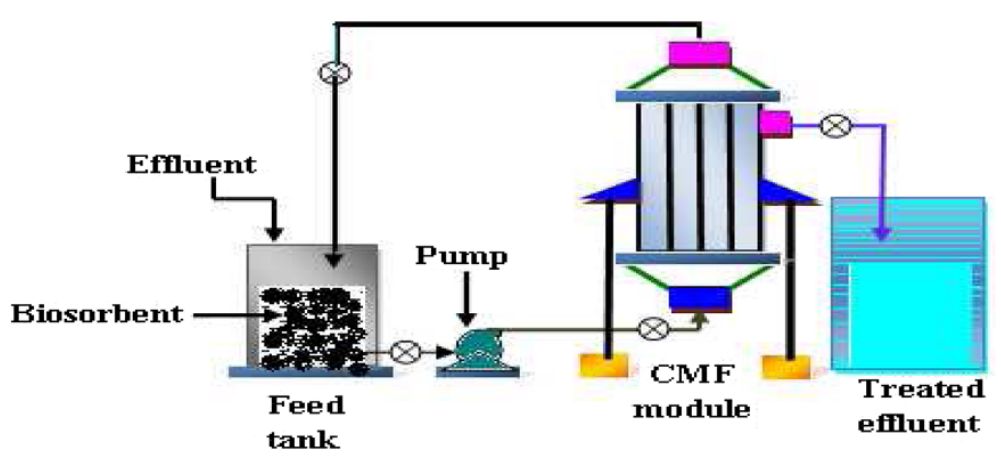

Figure 2 Schematic representation of the experimental setup involving biosorbent and crossflow microfiltration.

water permeability value could be restored almost completely which was about 45 to $60 \mathrm{~min}$.

\section{Collection of E. hirta L.}

The plant was collected from an unaffected area near the lakeside around Kolkata. Affected plants were also collected from the adjacent area of the common effluent treatment plant to compare the results. The plants were allowed to grow in laboratory conditions in hydroponic solutions with proper illumination and temperature. After 7 days time of acclimatization, the plants were immersed in seven different solutions in three replicates. The solutions were effluent 1 and permeate, effluent 2 and permeate, effluent 3 and permeate and fresh water (control).

\section{Antioxidative stress enzymes and biochemical assays}

Guaiacol peroxidase was measured by adding $990 \mu \mathrm{L}$ of guaiacol solution $(0.25 \% \mathrm{v} / \mathrm{v}$ in $10 \mathrm{mmol} / \mathrm{L}$ of phosphate buffer and $0.125 \% \mathrm{H}_{2} \mathrm{O}_{2}$ ) to $10 \mu \mathrm{L}$ of enzyme extract (extracted in phosphate buffer). The brown-coloured complex formed was measured spectrophotometrically at $470 \mathrm{~nm}$ and expressed as A470 per gram of fresh tissue weight per minute (Cipollani 1998). Superoxide dismutase was measured according to the method described by Giannopolitis and Ries using nitro blue tetrazolium (NBT) with slight modifications. After reaction, the sample was measured spectrophotometrically at 560 $\mathrm{nm}$ and expressed as unit per milligram of protein per minute (Giannopolitis and Stanley 1977). Catalase activity was measured by observing the disappearance of $\mathrm{H}_{2} \mathrm{O}_{2}$ spectrophotometrically at $240 \mathrm{~nm}$. The reaction mixture consisted of phosphate buffer, $\mathrm{H}_{2} \mathrm{O}_{2}$ and enzyme extract. The activity was expressed as unit per milligram of protein per minute (Aebi 1983).

The protein content of plant tissue was measured according to Lowry et al. (1951) using folin reagent and bovine serum albumin (BSA) standard. The colour intensity was measured spectrophotometrically at $660 \mathrm{~nm}$ and expressed as milligram per gram of fresh weight.
Total carbohydrate was measured by using anthrone with glucose as standard (Hedge and Hofreiter 1962). The samples were measured at $620 \mathrm{~nm}$ and expressed as milligram per gram of fresh weight. Amino acid content was measured by the formation of a red-coloured complex, i.e. formazone when reacted with ninhydrin in acidic medium and soluble in organic solvents like toluene (Bates et al. 1973). The samples were measured at $520 \mathrm{~nm}$ and expressed as micromole per gram of fresh weight. The chlorophyll content of plant leaves were measured according to APHA (Greenberg et al. 2005). Chlorophyll a and b were measured at 664 and $647 \mathrm{~nm}$ by extraction in ethanol. It was expressed as milligram per gram of fresh weight. For nucleic acid (DNA and RNA) determination, the plant tissues $(0.25 \mathrm{~g})$ were homogenized in $2 \mathrm{~mL}$ of cold methanol, and insoluble pellet was washed twice with same volume of methanol. The residue was extracted with $4 \mathrm{~mL}$ of cold perchloric acid $(0.2 \mathrm{M})$ and then by $4 \mathrm{~mL}$ of absolute ethanol. Further, the residue was extracted with $5 \mathrm{~mL}$ of $2: 1$ ethanol/ ether mixture at $50^{\circ} \mathrm{C}$ for $30 \mathrm{~min}$. The residue formed was extracted with $5 \mathrm{~mL}$ of $5 \%$ perchloric acid at $70^{\circ} \mathrm{C}$ for $40 \mathrm{~min}$. The supernatant $(1 \mathrm{~mL})$ was collected and 4 $\mathrm{mL}$ of diphenylamine reagent was added. It was kept in a water bath for $10 \mathrm{~min}$ and measured spectrophotometrically at $595 \mathrm{~nm}$ for DNA content. RNA content was measured by adding $1 \mathrm{~mL}$ of orcinol reagent to $1 \mathrm{~mL}$ of hydrolysate and measured at $660 \mathrm{~nm}$ (Cherry 1962). The chemicals used were purchased from Merck, GR, Bangalore, India.

\section{Statistical analysis}

Three replicates were performed for each treatment, and standard deviation (S.D.) was calculated and expressed in $X \pm$ S.D. using GraphPad InStat 3 software (GraphPad, San Diego, CA, USA) by one-way analysis of variance (ANOVA) in order to compare means of different treatments, taking $p \leq 0.05$ and $p \leq 0.01$ as levels of significance. 


\section{Results and discussion}

\section{Biosorptive treatment of tannery effluent}

From batch equilibrium study conducted to optimize dose of biosorbent and $\mathrm{pH}$ of sample solution, it was observed that for effluent 1 the optimum dose was $3 \mathrm{~g} / \mathrm{L}$, for effluent 2 the dose was $2 \mathrm{~g} / \mathrm{L}$ and for effluent 3 the dose was $0.5 \mathrm{~g} / \mathrm{L}$ (Figure $3 \mathrm{a}, \mathrm{b}, \mathrm{c}$ ). The association of biosorbent of toxic metals or organic matter present in effluent is generally electrostatic in nature. The interaction occurs between the available sites on biosorbent and metals or organic matter. At a given biosorbent dose, adsorption occurs until all the binding sites are exhausted and no more sites are available for sorption, i.e. the point of saturation is reached. Therefore, further increasing the dose does not increase the biosorption. Moreover, a higher amount of biosorbent results in blocking of binding sites from being available for uptake of organic matter or metal ions (Meena et al. 2004; Chhikara and Dhankhar 2008). Figure 3 indicated that the optimum $\mathrm{pH}$ for effluents 1 and 2 was 4 , and for effluent 3 , it was 5 . With increasing the $\mathrm{pH}$ of any system, the number of negatively charged sites increases and the number of positively charged sites decreases. As explained by Neelavathi et al. (2004), negatively charged surface on the sorbent sites does not favour the adsorption of anions due to electrostatic repulsion. This explains the reduced biosorption at higher $\mathrm{pH}$ which might be due to the abundance of $\mathrm{OH}^{-}$ions that caused decreased availability of adsorbable components for biosorption.

\section{Ceramic microfiltration assisted by biosorption process}

Three different types of effluents were treated using the combined process. In Figure 4, the COD and TKN removal were observed with time. Tannery effluent contains huge amounts of organic matter which are measured in terms of COD and TKN. It is necessary to consider the ratio of COD to TKN because chemical oxygen demand in wastewater results in the prevalence of anaerobic conditions in the biological treatment process. The presence of high TKN is due to the use of animal's hides, skins which contribute nitrogen in organic and inorganic forms. High COD and TKN contribute to high nutrients in wastewater which must be removed or reduced by treatment before discharge or else it might result in eutrophication (Oke et al. 2006). From Figure 4a it might be observed that COD reduction for effluents 1, 2 and 3 for different days were about $96 \%$ to $97 \%, 92 \%$ to $94 \%$ and $90 \%$ to $93 \%$, respectively. It might be observed that COD reduction for effluent 1 was slightly more than that for effluents 2 and 3 . This might be due to the cake layer formation on the surface of the membrane resulting from the higher solute loading of effluent 1 which provided more resistance towards permeate flow, as well as partial adsorption of some of the components resulting in higher organic matter removal. TKN reduction for effluents 1,2 and 3 was about $86 \%, 86.3 \%$ and $94.2 \%$, respectively (Figure $4 \mathrm{~b}$ ). Table 1 showed detailed characteristics of the effluents after treatment. It might be observed that apart from the substantive reduction of organic loading, as well as suspended and turbid components, the biosorption-induced method could effectively reduce the heavy metal contents, viz. chromium, lead, nickel and other inorganic constituents, viz. potassium, phosphorus, sulphide, etc. Being biologically treated, the secondary clarifier effluent (effluent 3 ) had a lower concentration of TKN compared to effluents 1 and 2, and the combination method of biosorption with ceramic microfiltration could adequately reduce the TKN.

Figure $5 \mathrm{a}$ represented permeate flux at a constant pressure of $1 \mathrm{~kg} / \mathrm{cm}^{2}$ for $180 \mathrm{~min}$. Since COD loading of effluent 1 was higher compared to effluents 2 and 3, a flux value of about 9 to $15 \mathrm{~L} / \mathrm{m}^{2} / \mathrm{h}(\mathrm{LMH})$ was obtained. For effluent 2, about 17.9 to $21 \mathrm{LMH}$ of flux was obtained and for effluent 3 it was about 23.5 to 27.5 LMH. A steady state flux was obtained for all three types of effluent. Microfiltration study was also conducted at varying pressure (Figure 5b) to observe the effect of pressure on steady state flux. Pressure was varied from 0.4 to $2.2 \mathrm{~kg} / \mathrm{cm}^{2}$. Flux rate increased with increasing pressure.

\section{Effect on antioxidative stress enzymes}

From Table 2 it might be observed that the maximum enzyme activity (POD, SOD and CAT) was exhibited by effluent 1 followed by effluents 2 and 3 . The plant when exposed to treated (by combined process) water exhibited much lower enzyme activity. It was observed that for effluent 1, the POD activity of Euphorbia sp. (approximately 1.6-fold) was much higher $(p \leq 0.01)$ than that of the control which reduced to approximately 1.2 when exposed to permeate water after $72 \mathrm{~h}$. Similarly, the plant grown in effluent 2 (approximately 1.32 -fold) had a much higher ( $p \leq 0.01$ ) enzyme activity which was reduced (approximately 1.14-fold) for that in the treated effluent. Interestingly, since effluent 3 had a much lower loading, the enzyme activity (approximately 1.2-fold) was not much higher $(p \leq 0.01)$ and the treated effluent resulted in a much lower enzyme activity comparable to that of the control values. For SOD activity, it was observed that effluent 1 exhibited maximum activity (approximately fourfold) which was reduced (approximately 1.75-fold) for that in the treated water. Enzyme activity of the plant (approximately 3.7-fold) in effluent 2 was reduced after being subjected to the treated effluent (approximately 1.72-fold). Enzyme activity for effluent 3 (approximately 3.15-fold) was higher $(p \leq 0.01)$, but for the plant in the treated effluent, it was not significantly higher $(p \leq 0.01)$ than that of the control. Similarly, it might be observed that the 

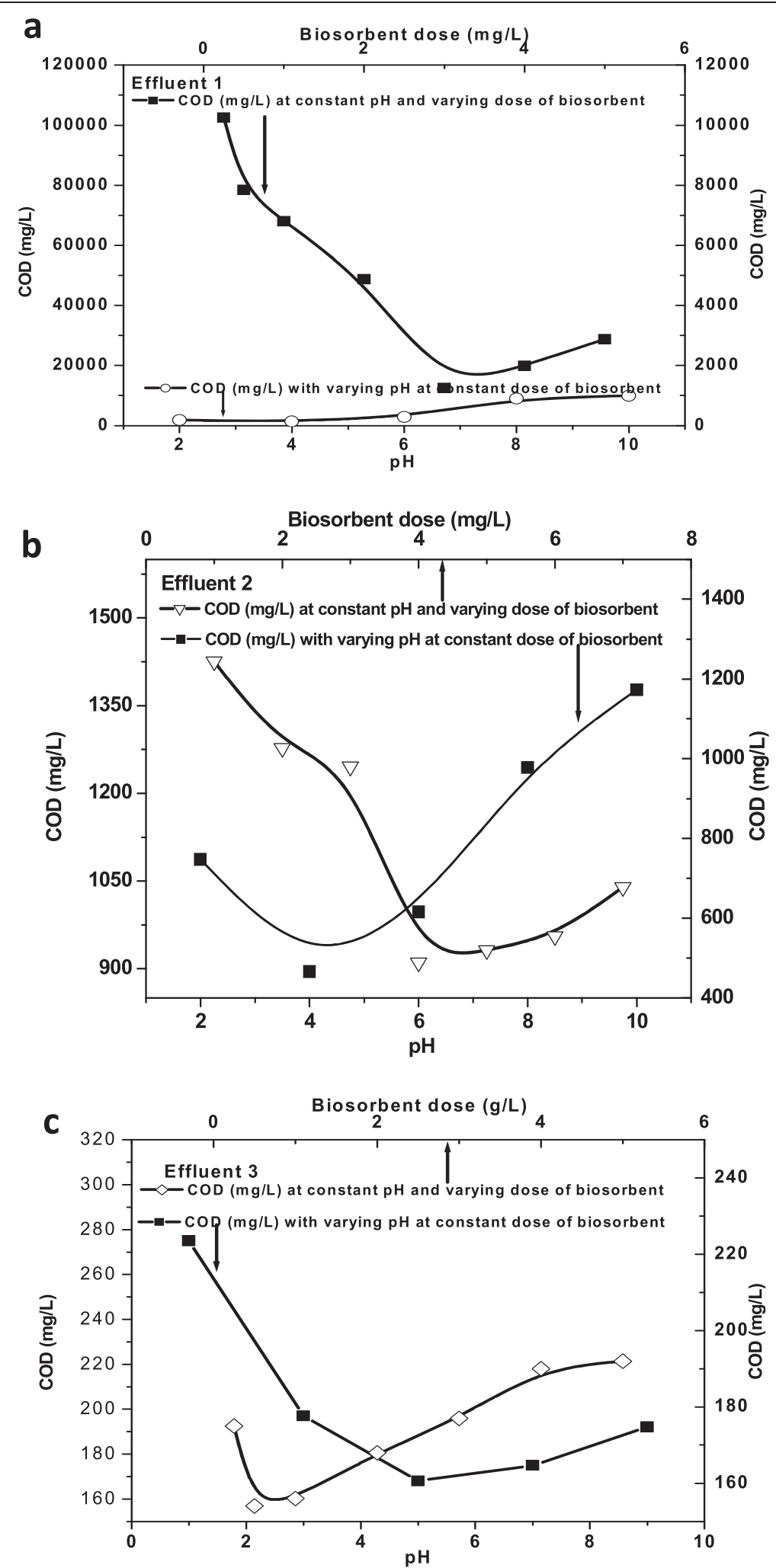

Figure 3 COD removal in batch biosorption study. Using varying $\mathrm{pH}$ at constant biosorbent dose and at constant pH with varying biosorbent dose: (a) effluent 1, (b) effluent 2 and (c) effluent 3. 

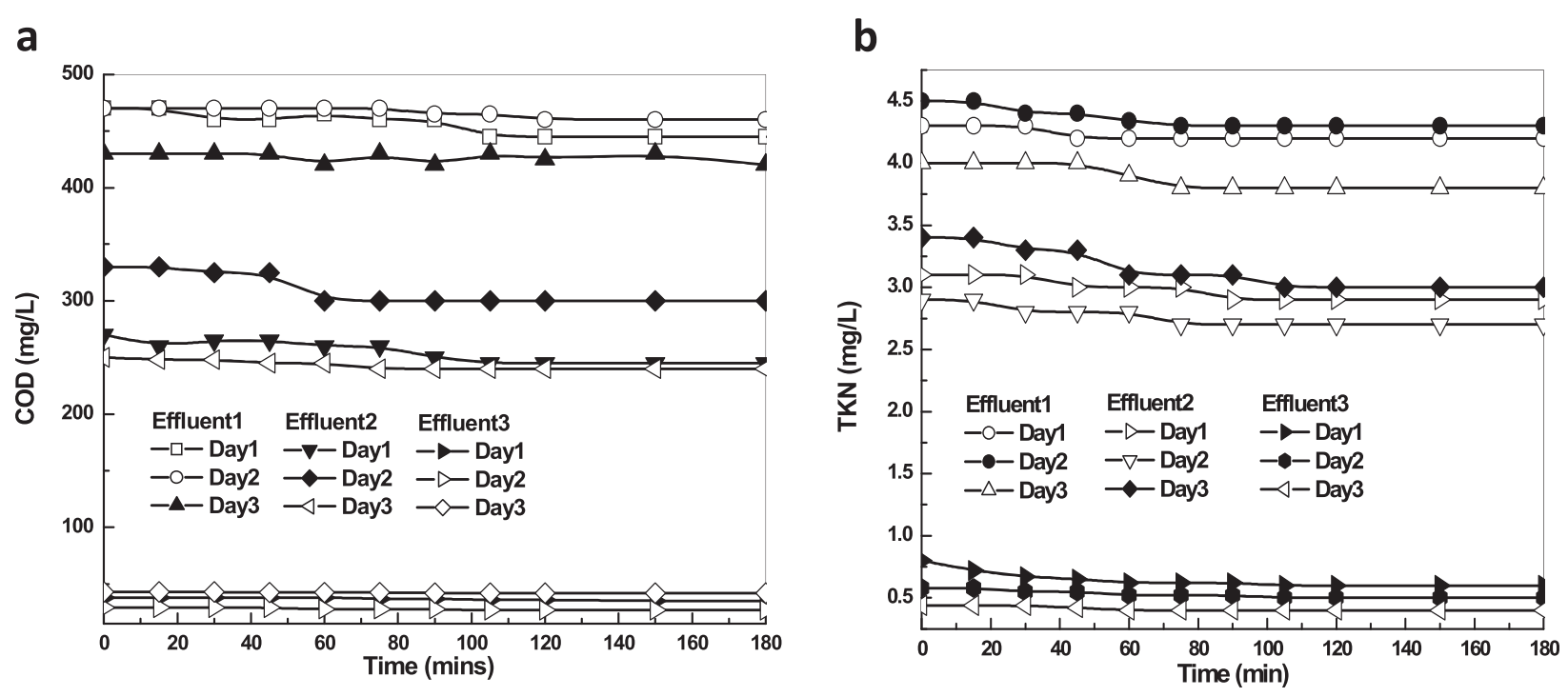

Figure 4 COD vs time (a) and TKN vs time (b) for tannery effluent on different days.

catalase activity of the plant in effluent 1 (approximately 3.23-fold) decreased when grown in the treated effluent (approximately 1.6-fold), and for effluent 2 (approximately 2.76-fold), it decreased to approximately 1.5 -fold ( $p \leq 0.01$ ). Enzyme activity of the plant in effluent 3 (approximately 2.06 -fold) reduced to approximately 1.3 -fold, and data was comparable to that of the control. Peroxidases are widely distributed in plant cells especially in plasma membrane. These enzymes show an increased activity when exposed to various stress-causing factors. These enzymes are located in the cytosol, cell wall, vacuole, etc. Studies have shown that an increase in POD activity was observed in mulberry leaves due to fluoride toxicity (Anil et al. 2009).
Superoxide dismutase is generally associated with the first-line defence of organisms against reactive oxygen species. These enzymes catalyze the dismutation of superoxide radicals to oxygen and hydrogen peroxide and are widely distributed in different subcellular compartments of plant cells. The enzymes are generated to protect the plant cells from environmental stress (Bowler et al. 1994). Catalase enzyme activity changes with metabolic activity and environmental factors. Quantification of the enzyme activity determines the effect of stress or chemicals, etc. on plant metabolism. Catalase activity increased in soybean due to the application of zinc and salinity stress (Weisany et al. 2012). a

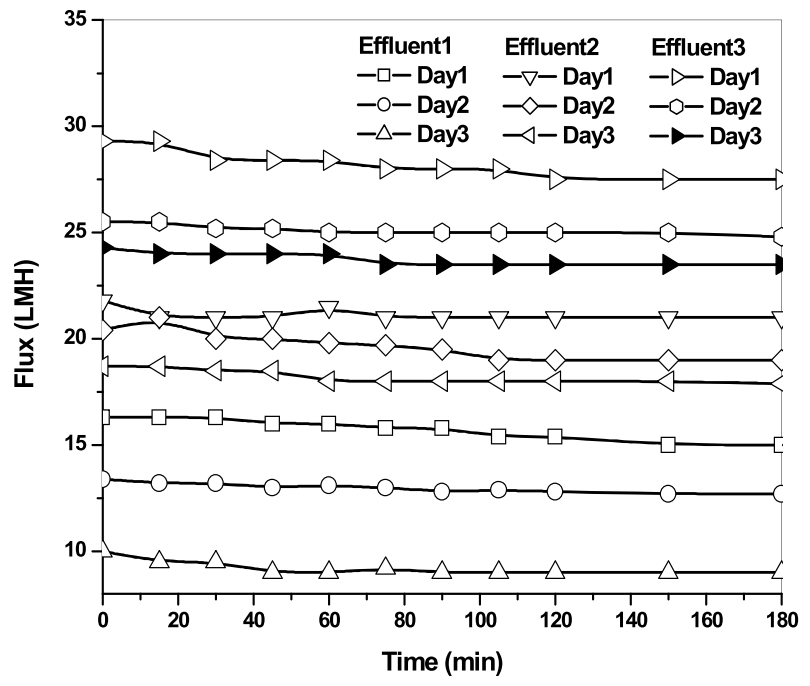

b

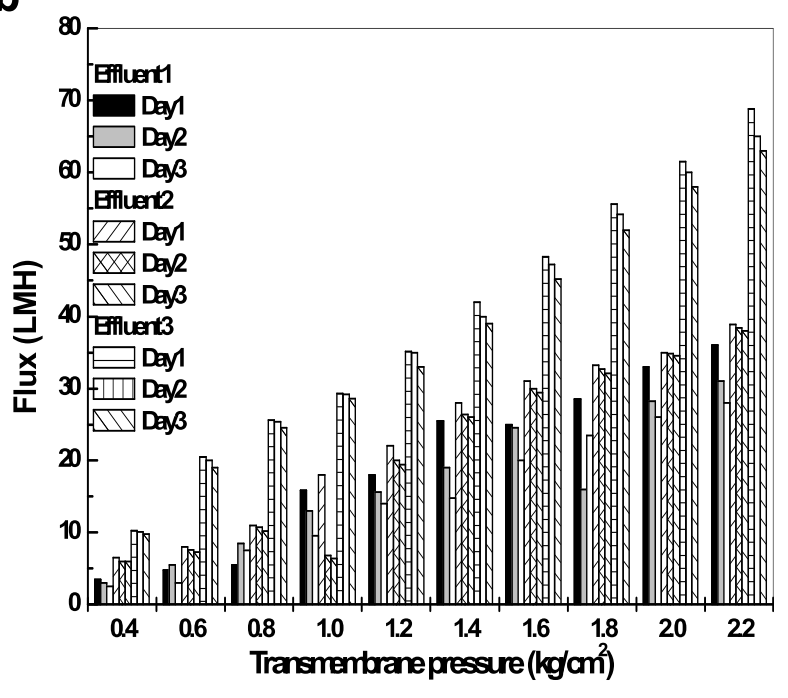

Figure 5 Flux vs time (a) and variation of flux (b) with transmembrane pressure for tannery effluent on different days. 
Table 2 Oxidative stress enzymes of Euphorbia sp. plant exposed to various types of tannery effluent

\begin{tabular}{|c|c|c|c|c|}
\hline \multirow[t]{2}{*}{ Oxidative stress enzymes } & \multirow[t]{2}{*}{ Experiment groups } & \multicolumn{3}{|c|}{ Plant exposure time } \\
\hline & & $24 \mathrm{~h}$ & $48 \mathrm{~h}$ & $72 \mathrm{~h}$ \\
\hline \multirow[t]{7}{*}{$\mathrm{POD}(\triangle \mathrm{A} 470 \mathrm{~g}$ fresh weight $/ \mathrm{min})$} & Control & $15.4 \pm 0.2$ & $14.8 \pm 0.2$ & $14.2 \pm 0.1$ \\
\hline & Effluent 1 untreated & $23.8 \pm 0.2$ & $23.5 \pm 0.1$ & $22.9 \pm 0.2$ \\
\hline & Effluent 1 treated & $17.7 \pm 0.1$ & $17.2 \pm 0.1$ & $16.8 \pm 0.1$ \\
\hline & Effluent 2 untreated & $19.5 \pm 0.2$ & $19.2 \pm 0.2$ & $18.8 \pm 0.2$ \\
\hline & Effluent 2 treated & $17.1 \pm 0.1$ & $16.8 \pm 0.1$ & $16.2 \pm 0.2$ \\
\hline & Effluent 3 untreated & $18 \pm 0.2$ & $17.8 \pm 0.1$ & $17.2 \pm 0.1$ \\
\hline & Effluent 3 treated & $15.6 \pm 0.2$ & $15.0 \pm 0.2$ & $14.5 \pm 0.1$ \\
\hline \multirow[t]{7}{*}{ SOD (U/mg protein) } & Control & $2.9 \pm 0.1$ & $2.6 \pm 0.1$ & $2.0 \pm 0.1$ \\
\hline & Effluent 1 untreated & $9.1 \pm 0.1$ & $8.9 \pm 0.1$ & $8.6 \pm 0.1$ \\
\hline & Effluent 1 treated & $4.1 \pm 0.1$ & $3.8 \pm 0.1$ & $3.5 \pm 0.1$ \\
\hline & Effluent 2 untreated & $7.9 \pm 0.1$ & $7.6 \pm 0.1$ & $7.4 \pm 0.1$ \\
\hline & Effluent 2 treated & $3.9 \pm 0.1$ & $3.6 \pm 0.1$ & $3.44 \pm 0.1$ \\
\hline & Effluent 3 untreated & $6.8 \pm 0.1$ & $6.6 \pm 0.1$ & $6.3 \pm 0.1$ \\
\hline & Effluent 3 treated & $3.3 \pm 0.1$ & $3.1 \pm 0.1$ & $2.7 \pm 0.1$ \\
\hline \multirow[t]{7}{*}{ CAT (U/mg protein/min) } & Control & $4.4 \pm 0.2$ & $3.2 \pm 0.1$ & $3.0 \pm 0.2$ \\
\hline & Effluent 1 untreated & $11.3 \pm 0.1$ & $10.8 \pm 0.1$ & $9.7 \pm 0.2$ \\
\hline & Effluent 1 treated & $5.8 \pm 0.2$ & $5.1 \pm 0.2$ & $4.8 \pm 0.2$ \\
\hline & Effluent 2 untreated & $9.6 \pm 0.1$ & $8.8 \pm 0.2$ & $8.3 \pm 0.2$ \\
\hline & Effluent 2 treated & $4.9 \pm 0.1$ & $4.7 \pm 0.2$ & $4.52 \pm 0.1$ \\
\hline & Effluent 3 untreated & $7.7 \pm 0.2$ & $7.7 \pm 0.2$ & $6.2 \pm 0.2$ \\
\hline & Effluent 3 treated & $4.6 \pm 0.1$ & $4.1 \pm 0.2$ & $3.8 \pm 0.1$ \\
\hline
\end{tabular}

Values are mean \pm S.D.; $p<0.01$.

\section{Effect on biochemical parameters}

From Figure 6 it might be observed that there was considerable reduction in amino acid content of the plant exposed to untreated effluent, i.e. approximately $43 \%$ for effluent 1, 11\% for effluent 2 and $7 \%$ for effluent 3 . Interestingly, amino acid content for the plant exposed to treated effluent 3 was more than that of the control which might be due to the presence of macro- and micronutrients. Apart from that, treatment of both effluents 1 and 2 resulted in increased amino acid content compared to untreated effluent after $72 \mathrm{~h}$ of exposure. A similar trend was observed for carbohydrate content where there was also about $39 \%, 6 \%$ and $5.3 \%$ reduction of carbohydrate content observed in the plants exposed to effluents 1, 2 and 3. Carbohydrate content also increased compared to that of the control for plants grown in treated effluent 3. Both carbohydrate and amino acid contents were reduced due to environmental stress caused by untreated effluent. A similar effect was also observed by Bamniya et al. for Brassica sp. and Spinacia sp. (Bamniya et al. 2010). Protein content of plants exposed to effluent 1 and 2 showed a reduction of about $42 \%$ and $30 \%$, but there was considerable increase in protein content for plants exposed to untreated and treated effluent 3. Protein content of plants decreased due to more mobilization of protein under stress condition. In the case of chlorophyll content, about $62 \%, 43 \%$ and $34 \%$ for chlorophyll a and 48\%, 23\% and $9 \%$, respectively, for chlorophyll b were observed for the plants growing in effluents 1, 2 and 3. For both chlorophyll $a$ and $b$, the value was comparable to that of the control for plants exposed to treated effluent 3. Scientists have observed that heavy metal toxicity can hamper the chlorophyll a/b ratio. Reduction in chlorophyll a compared to $b$ is due to its faster hydrolysis. Changes in the concentration of chlorophyll a and b determine the effect of environmental stress on plants. Chlorophyll content decreases under stress due to inhibition of various enzymes like $\delta$-aminolevulinic acid dehydratase and protochlorophyllide, subsequently affecting the photosynthetic machinery (Ahmad et al. 2007; Manios et al. 2003; Palma et al. 2002; Singh and Singh 2006; Sangeetha et al. 2012). DNA content for plants exposed to effluents 1, 2 and 3 was reduced to about $77 \%, 60.6 \%$ and $33 \%$, which increased for plants grown in treated effluent. DNA content of plants grown in treated effluent 3 was comparable with that of the control. About 44\%, 35\% and $8 \%$ reduction in RNA content was noticed for plants grown in effluents 1 , 2 and 3 . RNA content increased compared to that of the 


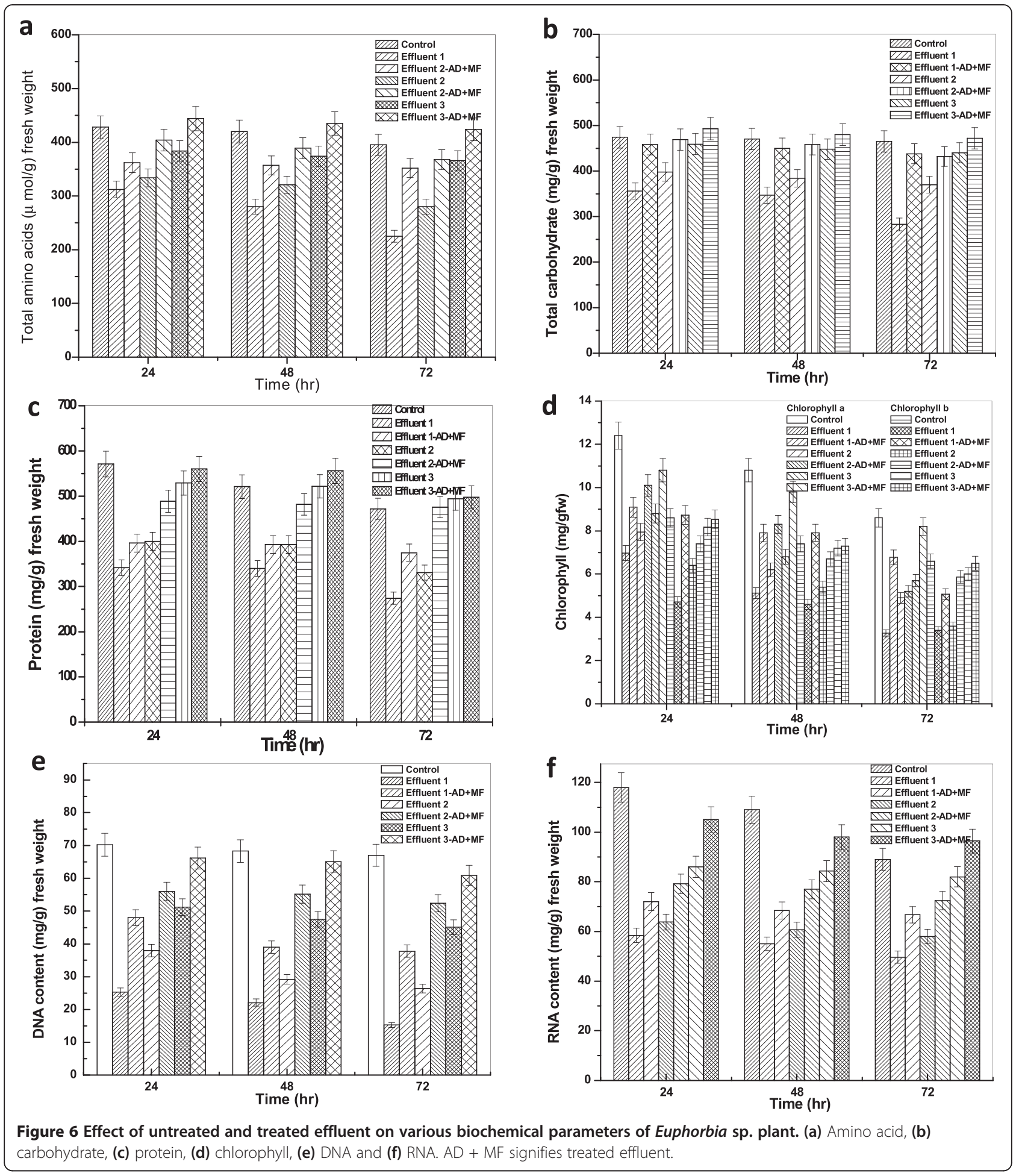

control for plants grown in treated effluent 3. Decreased content of DNA and RNA is associated with increased activity of DNAse and RNAse, respectively, in response to stress. Certain heavy metals like $\mathrm{Cu}, \mathrm{Cd}, \mathrm{Pb}, \mathrm{Hg}, \mathrm{Cr}$, etc. resulted in decreased DNA and RNA content (Prasad and Strzalka 2002).

\section{Conclusions}

The present study was conducted to evaluate the efficiency of ceramic membranes in combination with a biosorbent prepared from waste biomass. Three different loadings of wastewater were used in the experiment to observe the versatility of the combined process. The treated 
effluents showed considerable reduction of organic loading, suspended solids, total organic carbon and nitrogen content. About $99 \%$ reduction of heavy metals like $\mathrm{Cr}, \mathrm{Ni}$ and $\mathrm{Pb}$ was achieved in the combined process. Maximum removal was obtained for the secondary clarifier effluent where most of the parameters were far below the discharge limit. At an operating pressure of $1 \mathrm{~kg} / \mathrm{cm}^{2}$, the flux value of effluent 1 was about 9 to $15 \mathrm{LMH}$, whereas for effluent 2 it was about 17.9 to $21 \mathrm{LMH}$ and for effluent 3 it was about 23.5 to $27.5 \mathrm{LMH}$.

The main aim of the study was to treat wastewater to an extent so that it could be utilized for irrigation and agricultural purpose. For this, the authors have selected $E$. hirta as a model plant being found growing abundantly in the complex of CETP in diseased condition. The target was to propose a single-step treatment technology for onsite application to reduce the level of pollutants from the wastewater so that less harm is imparted to the environment. The application of treated water resulted in considerable reduction in the activity of various stress enzymes like POD, SOD and CAT compared to that of untreated wastewater. Considerable reduction in protein content (approximately 42\%), carbohydrate content (approximately $39 \%$ ), chlorophyll a and b content (approximately $62 \%$ and $48 \%$ ), DNA (approximately 77\%) and RNA ( 44\%) was observed for plants grown in effluent 1. A similar trend was also observed for effluents 2 and 3 . Interestingly, amino acid, protein and carbohydrate content increased to about approximately onefold in plants exposed to treated effluent 3. Moreover, chlorophyll content of the plant was comparable to that grown in the control. Therefore, it might be concluded that the combined technology may be used for the treatment of highly toxic and pollutive tannery effluent and reused for various purposes including agriculture, irrigation, etc.

\section{Competing interests}

The authors declare that they have no competing interests.

\section{Authors' contributions}

SG carried out the design of the experiments, supervised the overall engineering aspects of the study, took care of the microfiltration study. PB prepared the biosorbent, collected effluent samples, conducted the treatment study. AM looked into the environmental aspects of the study wrt to plant enzyme activity. All the authors read and approved the final manuscript.

\section{Acknowledgements}

This study was conducted under the CSIR-Network project, NWP0044 under the $11^{\text {th }}$ Five Year Plan, funded by the CSIR, Government of India.

\footnotetext{
Author details

${ }_{1}^{1}$ Ceramic Membrane Division, CSIR-Central Glass and Ceramic Research Institute, 196 Raja S.C. Mullick Road, Kolkata 700032, India. ${ }^{2}$ Department of Environmental Science, University of Calcutta, 35 Ballygunge Circular Road, Kolkata 700 019, India.
}

Received: 20 March 2013 Accepted: 23 September 2013

Published: 01 Oct 2013

\section{References}

Aebi HE (1983) Catalase. In: Bergmeyer HU (ed) Methods of enzymatic analyses, vol 3. Verlag Chemie, Weinheim, pp 273-282

Ahmad P, Sharma S, Srivastava PS (2007) In vitro selection of $\mathrm{NaHCO}_{3}$ tolerant cultivars of Morus alba (Local and Sujanpuri) in response to morphological and biochemical parameters. Hort Sci 34:114-122

Altaf MM, Masood F, Malik A (2008) Impact of long-term application of treated tannery effluents on the emergence of resistance traits in Rhizobium sp. isolated from Trifolium alexandrinum. Turk J Biol 32:1-8

Anglada A, Urtiaga A, Ortiz I (2009) Contributions of electrochemical oxidation to waste-water treatment: fundamentals and review of applications. J Chem Technol Biot 84(12):1747-1755

Anil KK, Varaprasad P, Vijaya Bhaskara Rao A (2009) Effect of fluoride on catalase, guiacol peroxidase and ascorbate oxidase activities in two verities of mulberry leaves (Morus alba L.). Res J Earth Sci 1(2):69-73

Bamniya BR, Kapasya V, Kapoor CS (2010) Physiological and biochemical studies on the effect of waste water on selected crop plants. Biol Forum Int J 2(2):1-3

Bandyopadhyay S, Kundu D, Roy SN, Ghosh BP, Maiti HS (2006) Process for preparing water having an arsenic level of less than 10 PPB., US Patent. 7014771

Bates LS, Waldran RP, Teare ID (1973) Rapid determination of free proline for water stress studies. Plant Soil 39:205-207

Bhattacharya P, Dutta S, Ghosh S, Vedajnananda S, Bandyopadhyay S (2010) Crossflow microfiltration using ceramic membrane for treatment of sulphur black effluent from garment processing industry. Desalination 261:62-72

Bhattacharya P, Ghosh S, Sarkar S, Majumdar S, Bandyopadhyay S (2011) Effectiveness of biosorption-assisted microfiltration process for treatment of domestic wastewater. Bioremediation J 15(4):206-217

Bhattacharya P, Banerjee P, Mallick K, Ghosh S, Majumdar S, Mukhopadhyay A, Bandyopadhyay S (2013) Potential of biosorbent developed from fruit peel of Trewia nudiflora for removal of hexavalent chromium from synthetic and industrial effluent: analyzing phytotoxicity in germinating Vigna seed. J Environ Sci Heal A: Toxic/Hazard Subs and Environ Eng 48:706-719

Bowler C, Camp WV, Montagu MV, Inzéb D, Asadac K (1994) Superoxide dismutase in plants. Cr Rev Plant Sci 13(3):199-218

Cassano A, Molinali R, Romomo M, Drioli E (2001) Treatment of aqueous effluents of the leather industry by membrane processes a review. J Membrane Sci 181:111-126

Chena GQ, Zhanga WJ, Zenga GM, Huanga JH, Wanga L, Shen GL (2011) Surfacemodified Phanerochaete chrysosporium as a biosorbent for $\mathrm{Cr}(\mathrm{VI})$ contaminated wastewater. J Hazard Mat 186:2138-2143

Cherry JH (1962) Nucleic acid determination in storage tissues of higher plants. Plant Physiol 37(5):670-678

Chhikara S, Dhankhar R (2008) Biosorption of Cr (VI) ions from electroplating industrial effluent using immobilized Aspergillus niger biomass. J Environ Biol 29(5):773-778

Cipollani DF (1998) The induction of soluble peroxidase activity in bean leaves by wind-induced mechanical perturbation. Am J Bot 85(11):1586-1591

Dogruel S, Genceli EA, Babuna FG, Orhon D (2004) Ozonation of nonbiodegradable organics in tannery wastewater. J Environ Sci Health A Toxic/Hazard Subst Environ Eng 39(7):1705-1715

Espinoza-Quinones F, Fornari M, Modenes AN, Palacio SM, Silva FG, Szymanski N, Kroumov AD, Trigueros D (2009) Pollutant removal from tannery effluent by electrocoagulation. Chem Eng J 151:59-65

Giannopolitis CN, Stanley KR (1977) Superoxide dismutases occurrence in higher plants. Plant Physiol 59(2):309-314

Goltara A, Martinez J, Mendez R (2009) Carbon and nitrogen removal from tannery wastewater with a membrane bioreactor. Water Sci Technol 48(1):207-214

Greenberg AE, Eaton AD, Clesceri LS, Rice EW (2005) Standard methods for the examination of water and wastewater, 21st edn. APHA, AWWA, WEF, Washington, D.C

Gupta MC (1987) Effects of coal-smoke pollutants from different sources on the growth, chlorophyll content, stem anatomy and cuticular traits of Euphorbia hirta L. Environ Pollut 47(3):221-229

Hedge JE, Hofreiter BT (1962) In: Whistler RL, Be Miller JN (eds) Carbohydrate chemistry, 17th edn. Academic, New York

Holm LG, Plucknett DL, Pancho JV, Herberger JP (1991) The world's worst weeds. Distribution and biology. University Press of Hawaii, Honolulu

Keerthi SV, Mahalakshmi M, Balasubramanian N (2013) Development of hybrid membrane bioreactor for tannery effluent treatment. Desalination 309:231-236 
Lowry OH, Rosebrough NJ, Farr AL, Randall RJ (1951) Protein measurement with the folin phenol reagent. J Biol Chem 193(1):265-275

Manios T, Stentiford El, Millner PA (2003) The effect of heavy metals accumulation on the chlorophyll concentration of Typha latifolia plants, growing in a substrate containing sewage sludge compost and watered with metaliferus water. Ecol Eng 20:65-74

Meena AK, Mishra GK, Kumar S, Rajagopal C, Nagar PN (2004) Adsorption of Cd(II) ions from aqueous solution using different adsorbents. Ind I Scientific Indus Res 63:410-416

Neelavathi A, Chandrashekhar KB, Rameshbabu C, Jayaveera KN (2004) Removal of toxic $\mathrm{Cr}(\mathrm{VI})$ by the adsorption of activated carbons prepared from Simarouba shells. J Environ Sci Eng 46:137-142

Oke IA, Otun JA, Okuofu CA, Olarinoye NO (2006) Characteristics of tanning industries in Nigeria for aquatic animals and plants. Res J Agri Bio Sci 2(5):209-217

Palma JM, Sandalio LM, Javier CF, Romero-Puertas MC, McCarthy I, Del RLA (2002) Plant proteases protein degradation and oxidative stress: role of peroxisomes. Plant Physiol Bioche 40:521-530

Prajapati ND, Purohit SS, Sharma AK, Kumar T (2003) Handbook of medicinal plants. Agrobios, Jodhpur

Prasad MNV, Strzalka K (2002) Physiology and biochemistry of heavy metal toxicity and tolerance in plants. Kluwer, Dordrecht

Rameshraja D, Suresh S (2011) Treatment of tannery wastewater by various oxidation and combined processes. Int J Environ Res 5(2):349-360

Rodrigues MAS, Amado FDR, Xavier JLN, Streit KF, Bernardes AM, Ferreira J (2008) Application of photoelectrochemical-electrodialysis treatment for the recovery and reuse of water from tannery effluents. J Clean Prod 16:605-611

Sangeetha R, Kamalahasan B, Karthi N (2012) Use of tannery effluent for irrigation: an evaluative study on the response of antioxidant defenses in maize (Zea mays). Int Food Res J 19(2):607-610

Scholz WG, Rouge P, Bodalo A, Leitz U (2005) Desalination of mixed tannery effluent with membrane bioreactor and reverse osmosis treatment. Environ Sci Technol 39(21):8505-8511

Singh VK, Singh J (2006) Toxicity of industrial wastewater to the aquatic plant Lemna minor L. J Environ Biology 27(2):385-390

Sivaprakasam S, Mahadevan S, Sekar S, Rajakumar S (2008) Biological treatment of tannery wastewater by using salt-tolerant bacterial strains. Microb Cell Fact 7(15):1-7

Stephenson T, Judd S, Jefferson B, Brindl K (2000) Membrane bioreactors for wastewater treatment. IWA, London

Suthanthararajan R, Ravindranath E, Chitra K, Umamaheswari B, Ramesh T, Rajamani S (2004) Membrane application for recovery and reuse of water from treated tannery wastewater. Desalination 164(1):151-156

Tabugo SRM, Rampola RB, Vasallo E Jr, Madamba MRSB (2013) Assessment of the safety of tawa-tawa (Euphorbia hirta L.) decoction as alternative folkloric medicine. Glob J Med Plant Res 1(2):177-183

Vasudevan N, Justin Aaron PS, Greeshma O (2012) Performance evaluation of a common effluent treatment plant for tannery industries. J Ecobiotechnol 4(1):25-28

Weisany W, Sohrabi Y, Heidari G, Siosemardeh A, Ghassemi-Golezani K (2012) Changes in antioxidant enzymes activity and plant performance by salinity stress and zinc application in soybean (Glycine max L.). Plant Omics J 5(2):60-67

\subsection{6/2251-7715-2-19}

Cite this article as: Bhattacharya et al: Combination technology of ceramic microfiltration and biosorbent for treatment and reuse of tannery effluent from different streams: response of defence system in Euphorbia sp.. International Journal Of Recycling of Organic Waste in Agriculture 2013, 2:19

\section{Submit your manuscript to a SpringerOpen ${ }^{\circ}$ journal and benefit from:}

- Convenient online submission

- Rigorous peer review

- Immediate publication on acceptance

- Open access: articles freely available online

- High visibility within the field

- Retaining the copyright to your article

Submit your next manuscript at $>$ springeropen.com 